\title{
Sources and biological actions of relaxin in pigs
}

\author{
C. A. Bagnell ${ }^{1}$, Q. Zhang ${ }^{1}$, B. Downey ${ }^{2}$ and L. Ainsworth ${ }^{3}$ \\ 'Department of Animal Sciences, Rutgers University, New Brunswick, N] 08903, USA; ${ }^{2}$ Department \\ of Animal Science, Macdonald Campus of McGill University, Ste Anne de Bellevue, Quebec, \\ Canada H9X 3V9; and ${ }^{3}$ Centre for Food and Animal Research, Building 34 Central Experimental \\ Farm, Ottawa, Ontario, Canada K1A OC6
}

\begin{abstract}
Although the major source of relaxin in pigs is the corpus luteum of pregnancy, there is now evidence for relaxin gene expression and translation into protein in the theca interna cells of the preovulatory follicle, the corpus luteum of the cycle and the uterus. The theca interna cells retain their ability to express the relaxin gene and protein following ovulation. During the early stages of development of the corpus luteum, the theca-derived small lutein cells are the source of the relaxin transcript. As the corpus luteum becomes fully functional, there is a switch in the site of relaxin synthesis from small theca-derived lutein cells to large granulosa-derived cells. In the absence of luteolysis, this switch is accompanied by a dramatic rise in relaxin synthesis. Relaxin has been identified in boar seminal plasma and can maintain or increase sperm motility. However, a source of relaxin in the boar has not been identified. Relaxin is an important regulator of uterine function during pregnancy acting systemically to suppress myometrial activity and promote cervical dilation at parturition. The changes in thecal relaxin production during follicle development and its ability to promote growth and changes in proteolytic enzyme activity of granulosa cells in vitro have led to the concept of an autocrine or paracrine role for relaxin within the follicle. Uterotrophic effects of relaxin have been reported in rodents and swine and support the hypothesis that relaxin promotes uterine growth and expansion in early pregnancy to accommodate the growing fetuses. Mammotrophic effects of relaxin in rodents have now been extended to pigs, with evidence that relaxin is necessary for normal mammary parenchymal development in late pregnancy. In most instances the mechanisms responsible for, and the physiological significance of, these diverse biological effects remain to be elucidated.
\end{abstract}

\section{Introduction}

Relaxin was first recognized as an ovarian hormone by Hisaw et al. (1930) as a product of the porcine corpus luteum of pregnancy, having systemic actions on uterine smooth muscle and the connective tissue of the reproductive tract. Relaxin has been recognized as a hormone in a number of species; however, pigs remain the richest source and the importance of relaxin has been well established in porcine reproductive physiology.

Although the corpus luteum of pregnancy is a major source of relaxin, tissues from nonpregnant animals have also been reported to produce relaxin (Evans et al., 1983; Bagnell et al., 1990a). The identification of relaxin receptors (Mercado-Simmen et al., 1982) and observations of biological effects (Hall et al., 1990; Zhang and Bagnell, 1993) in tissues of nonpregnant pigs extend the scope of relaxin research beyond that of a 'hormone of pregnancy'.

The present paper will focus on relaxin by reviewing the literature and presenting some of the more recent research on nontraditional sources and roles for relaxin in porcine reproductive physiology. 
References to other species will be made as appropriate to provide a broader perspective and a basis for comparison. For other aspects of the physiology of relaxin in pigs (for example control of secretion, mechanism of action and receptors) the reader is referred to several comprehensive reviews (Schwabe et al., 1978; Porter, 1979a; Bryant-Greenwood, 1982; Sherwood, 1988).

\section{Chemistry of Relaxin}

Studies on the chemistry of relaxin focused initially on porcine relaxin owing to its abundance in the corpus luteum of pregnancy. The isolation of porcine relaxin (Sherwood and $O^{\prime} B y m e, 1974$ ) and the elucidation of its primary structure (Schwabe et al., 1976; James et al., 1977) were followed by development of specific and sensitive radioimmunoassays (Sherwood et al., 1975a; Afele et al., 1979). Recombinant DNA techniques were used to determine the nucleotide sequence of the gene coding for porcine relaxin and to produce the relaxin cDNA from mRNA of ovaries from pigs in late pregnancy (Haley et al., 1982).

Porcine relaxin is a $6.3 \mathrm{kDa}$ peptide consisting of an A chain of 22 amino acids and a B chain of 31 amino acids covalently linked by two disulfide bonds; the $A$ chain contains an intradisulfide linkage (Schwabe $e$ al., 1976; James et al., 1977). Relaxin is synthesized as a large, single-chain precursor, preprorelaxin, from which prorelaxin is formed by removal of a signal peptide ( 24 amino acids). Prorelaxin is then converted to a double chain structure after cleavage of a 104 amino acid connecting peptide (Gast, 1982, 1983). Plasma immunoreactive relaxin in pigs is secreted in a biologically active form, circulates unbound and has an amino acid composition similar to that of the form stored in the corpus luteum (O'Byrne et al., 1989). The structural similarity of relaxin to insulin and insulin-like growth factors (IGF), with respect to $A$ and $B$ chain lengths and the position of the disulfide bridges (Schwabe and McDonald, 1977), led to the postulate that these hormones constitute a family of peptides (Blundell and Humbel, 1980). However, there is only about $25 \%$ amino acid sequence similarity between relaxin and insulin (Issacs and Dodson, 1981). Relaxin does not compete for insulin (Olefsky et al., 1982) or IGF-I receptors (Hemandez et al., 1988) nor does porcine insulin displace porcine relaxin from its receptor in pig myometrium (Mercado-Simmen et al., 1982). Furthermore, there is no crossreactivity between relaxin and insulin in their respective radioimmunoassays (Rawitch et al., 1980; Greenwood et al., 1981).

\section{Sources of Relaxin in Female Pigs}

\section{Ovarian follicle}

Immunoreactive relaxin was first detected in porcine follicular fluid from cyclic and pregnant pigs, and segments of follicle wall were shown to produce relaxin in vitro (Bryant-Greenwood et al., 1980; Matsumoto and Chamley, 1980). Using isolated granulosa and theca cells from follicles of pregnant mares' serum gonadotrophin/human chorionic gonadotrophin (PMSG/hCG)-treated prepubertal gilts, Evans $e$ t al. (1983) found that the theca cell layer was the principal source of follicular relaxin. Using the same model, we have confirmed the production of relaxin by theca cells in vitro (Bagnell, 1991) and the presence of relaxin in the theca interna layer of the preovulatory pig follicle by immunohistochemical studies (Bagnell et al., 1987). More recently, using northern analysis and in situ hybridization, we demonstrated that relaxin gene expression is restricted to theca interna cells, and there was no evidence for relaxin mRNA in the granulosa cell layer (Bagnell et al., 1990b). Moreover, the distribution and relative concentration of relaxin mRNA parallels the production in vitro and immunohistochemical staining reported in the developing preovulatory follicle (Evans et al., 1983; Bagnell et al., 1987; Bagnell, 1991).

In contrast to the studies that have identified the theca interna as the principal source of follicular relaxin, other investigators have reported production of relaxin by granulosa cells. Loeken et al. (1983) found that granulosa cells from large porcine follicles released relaxin in response to LH in vitro (Loeken et al., 1983) and low amounts of relaxin mRNA were detected in extracts of porcine granulosa cells after culture with FSH and LH (Einspanier et al., 1986). In both of these studies, the granulosa cells were cultured in the presence 
of gonadotrophins, which are known to promote luteinization (Channing and Ledwitz-Rigby, 1975). In addition, relaxin has been found in luteinized granulosa cells of the human preovulatory follicle after ovarian hyperstimulation (Yki-jarvinen et al., 1984; Gagliardi et al., 1992) and in luteinized granulosa cells of the porcine corpus luteum (Bagnell et al., 1989). Collectively, these results suggest that luteinization of the granulosa cells may be required to activate expression of the relaxin gene and production of relaxin. Such a concept could provide a reasonable explanation for the apparent conflicting data on the source of follicular relaxin.

\section{Corpus luteum}

Low amounts of immunoreactive relaxin were detected in corpora lutea from cyclic pigs and maximum values were reached at about day 14 of the oestrous cycle (Sherwood and Rutherford, 1981; Denning. Kendall et al., 1989). This pattern of relaxin activity in the corpus luteum of the cycle is consistent with that found in peripheral blood (Messine et al., 1989) and with relaxin immunostaining of corpora lutea at different stages of the cycle (Ali et al., 1986; Bagnell et al., 1989; Denning-Kendall et al., 1989). There is also a suggestion that the pattern of relaxin secretion by the corpus luteum parallels that of progesterone (Kotwica et al., 1991).

During pregnancy, the corpus luteum is the principal source of relaxin in pigs. Bioactive relaxin in the corpus luteum increases steadily from about day 20 of pregnancy reaching maximum values at about day 110 and declining rapidly within $16 \mathrm{~h}$ of birth (Anderson et al., 1973). Concentrations of relaxin in plasma remain below $2 \mathrm{ng} \mathrm{ml}^{-1}$ until about day 100, then increase gradually to about $10 \mathrm{ng} \mathrm{ml}^{-1}$ three days before parturition. During the $48 \mathrm{~h}$ before farrowing the concentrations of relaxin increase markedly to 50$250 \mathrm{ng} \mathrm{ml}^{-1}$ about 24-14 $\mathrm{h}$ before farrowing. Thereafter, the concentrations decline rapidly to about $10 \mathrm{ng} \mathrm{ml}^{-1}$ (Sherwood et al., 1975b, 1981). The pattern of concentrations of relaxin in peripheral blood during pregnancy is consistent with the view that relaxin accumulates in electron-dense cytoplasmic granules in pregnancy and is released during their rapid degranulation and disappearance during the last two days of gestation (Belt et al., 1971; Kendall et al., 1978; Anderson et al., 1983).

Anderson et al. (1983) showed that in both pregnant and unmated gilts hysterectomized on day 6 of the cycle relaxin concentrations increased steadily until day 114 after oestrus. Thereafter, the relaxin concentrations in the pregnant gilts declined rapidly just before farrowing. In the hysterectomized group, relaxin concentrations declined steadily until day 120; there was then a gradual decrease to day 150 after oestrus. Anderson et al. (1983) postulate that relaxin release in ageing corpora lutea may be a precisely timed, genetically controlled event independent of endocrine control by the conceptuses or uterus. Although genetic control may contribute to the timing of relaxin release, there is evidence that other factors including the hypothalamic-pituitary axis (Felder et al., 1986) and luteal cells themselves (Huang et al., 1991) are involved.

A number of studies have demonstrated the presence of relaxin in porcine corpora lutea by immunohistochemistry. It was found that relaxin immunostaining increased to a peak by day 14 of the cycle (Fields and Fields, 1985; Ali et al., 1986; Bagnell et al., 1989). Thereafter, the immunostaining decreased as the corpora lutea regressed. In a more detailed study, with corpora lutea from nonpregnant and pregnant pigs, Denning-Kendall et al. (1989) showed that relaxin immunostaining in both types of corpora lutea was indistinguishable up to day 14 of the cycle. In the corpus luteum from nonpregnant pigs, the staining intensity decreased after day 14 . In contrast, the intensity of relaxin immunostaining increased markedly in the corpora lutea of pregnant pigs between days 11 and 14 and continued to increase in intensity up to day 31 of pregnancy. In addition, this study showed that histochemical staining for alkaline phosphatase, which is associated only with the small, theca interna-derived luteal cells (Corner, 1944) was restricted to the relaxin immunoreactive cells in the early luteal phase. As the corpus luteum developed there appeared to be a switch in the site of relaxin immunostaining to the large luteal cells which were not associated with alkaline phosphatase staining and may be derived from granulosa cells. This apparent switch in the site of relaxin immunostaining is most pronounced in the corpora lutea from pregnant pigs and was accompanied by a dramatic increase in relaxin content of the corpus luteum.

We have confirmed and extended those studies on the site of luteal relaxin production using a combination of northem analysis and in situ hybridization to follow the development of relaxin gene 
expression during corpus luteum development (Bagnell et al., 1993). Akaline phosphatase (AP) was used as a marker for theca interna-derived lutein cells and the relationship between AP-positive and relaxin mRNAcontaining cells was assessed. Corpora lutea obtained at various stages of development up to 19 days after ovulation were obtained from prepubertal gilts treated with PMSG/hCG to induce follicular development and ovulation. Northern analysis revealed that relaxin gene expression increased with development of the corpus luteum and reached maximum values at about day 14 after ovulation. Thereafter, as the corpus luteum regressed, the amount of relaxin mRNA declined. The question of the cellular source of luteal relaxin was studied using small and large cell populations isolated from corpora lutea of pigs at day 10 and 16 of the oestrous cycle. We showed that only small cells expressed relaxin mRNA at day 10, whereas at day 16 the large cells were the source of relaxin gene expression. In situ hybridization showed that the relaxin gene transcript was associated with cells corresponding to AP-positive small, luteinized theca cells until about day 9 after ovulation. Thereafter, the first AP-negative, granulosa-derived lutein cells expressing relaxin mRNA were observed. At day 14, relaxin hybridization and AP staining were distributed throughout the luteal tissue. With regression of the corpus luteum, both AP staining and relaxin hybridization declined.

Gast (1982) reported that RNA isolated from the corpus luteum of nonpregnant sows directed the synthesis of a protein with immunological and sequence identity to authentic relaxin. We confirmed and extended those studies by showing that relaxin mRNA is present in the corpora lutea of sows at early and midluteal phases of the cycle and increases during pregnancy (Bagnell et al., 1990b). By day 40 of pregnancy, luteal relaxin mRNA increased 50-fold over amounts observed at day 13 of the cycle (Bagnell et al., 1990a). Lobb and Porter (1992) extended these findings by pin-pointing the first indication of amplified relaxin gene expression at day 16 of pregnancy. A further increase in relaxin mRNA expression occurred at midpregnancy with a maximum at day 65 (Lobb and Porter, 1992). Evidence that this increase in relaxin gene expression in early pregnancy is translated into protein is reflected in a dramatic rise in content of immunoreactive relaxin in the corpus luteum between days 11 and 14 of pregnancy (DenningKendall et al., 1989).

Collectively, these studies on the source of luteal relaxin demonstrate the important contribution of the theca interna to formation of corpus luteum and development in pigs. The parallel fluctuations in relaxin transcript and relaxin protein imply active synthesis rather than sequestration of the hormone by luteal tissue. Although the significance of the switch in cell type producing relaxin during development of the corpus luteum is unknown, it is consistent with the observation that relaxin is secreted by large luteal cells of the fully developed corpus luteum (Taylor et al., 1987). The mechanisms that subserve the regulation of luteal relaxin synthesis and secretion are poorly understood. However, it has been shown that calcium mobilization, cyclic nucleotides, protein kinase activation and products of the cyclooxygenase pathway of arachidonic acid metabolism are implicated in the control of relaxin secreted by cultured porcine luteal cells in vitro (Taylor and Clark, 1988a, b, 1989; Taylor et al., 1987).

\section{Uterus}

The uterus produces relaxin in pregnant guinea-pigs (Pardo and Larkin, 1982), rabbits (Lee and Fields, 1990) and rats (Fields et al., 1992). The porcine uterus was studied as a possible source of the relaxin found in the plasma of lactating sows during suckling and nuzzling (Afele et al., 1979). Immunoreactive relaxin was isolated from uteri in pregnancy and lactation, but the low quantities detected were thought to represent receptor-bound hormone (Setliff and Greenwood, 1981). Immunoreactive relaxin was detected in the uterine epithelium of day 16 pregnant gilts, but not at day 13 of pregnancy nor on these days during the oestrous cycle (Zhang et al., 1992). Evidence that this represented relaxin production and not receptor-bound hormone was shown by reverse transcriptase-polymerase chain reaction studies which detected relaxin mRNA in endometrial tissue of day 16 pregnant gilts (Zhang et al., 1992).

\section{Sources of Relaxin in Male Pigs}

In boars, relaxin immunoactivity was reported to be associated with both interstitial and Sertoli cells of the testis (Dubois and Dacheux, 1978), but when antiserum against highly purified porcine relaxin was used, these results could not be confirmed (Arakaki et al., 1980; Yamamoto and Bryant-Greenwood, 


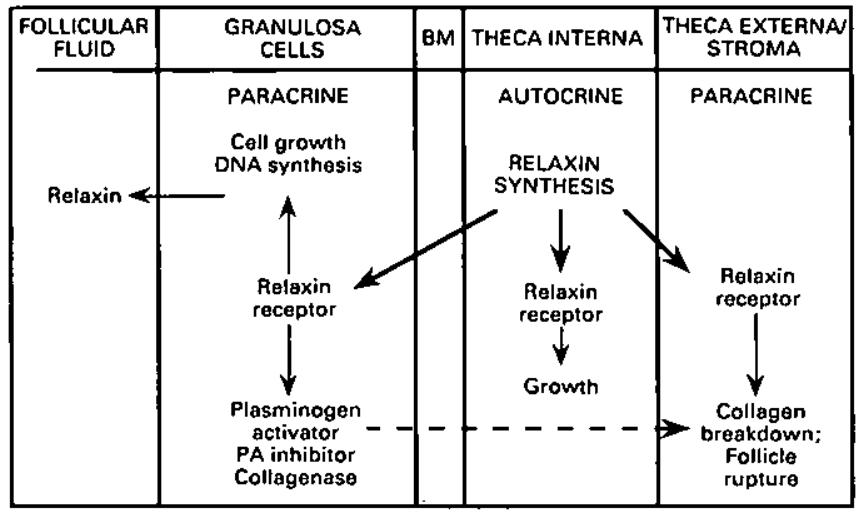

Fig. 1. Hypothesis for an autocrine or paracrine role of relaxin in the ovarian follicle. This hypothesis includes production of relaxin by theca intema cells which is detectable in follicular fluid, biological actions on cell growth and connective tissue protease activity via receptors in follicle compartments for locally produced relaxin. BM: basement membrane.

1981). Other studies have demonstrated the presence of immunoreactive relaxin in boar seminal plasma (Juang et al., 1990), but did not identify the site of production. The source of relaxin in boars requires further investigation.

\section{Biological Actions of Relaxin in Female Pigs}

\section{Follicular remodelling and growth}

The growing evidence for production of relaxin by theca interna cells of the developing preovulatory follicle, in the face of undetectable relaxin concentrations in the peripheral circulation at this time, has led to the hypothesis that relaxin may play an autocrine or paracrine role in the follicle (Bryant-Greenwood, 1982; Bagnell et al., 1984). Our current view of the way relaxin functions within the follicle is shown (Fig. 1). This working hypothesis meets in part the criteria established for an autocrine or paracrine system. These criteria include (1) local production: relaxin is a product of theca interna cells, (2) local action: relaxin acts on thecal cells (autocrine) or adjacent granulosa and theca externa/stromal cells (paracrine), (3) receptors on nearby target tissues to produce a biological response and (4) developmental alterations with changing physiological state, that is changes in production, action, receptor concentration and biological sensitivity.

An important biological action of relaxin is its ability to remodel collagen in its target tissues, the interpubic ligament and uterine cervix during pregnancy (Schwabe et al., 1978). The process of collagen remodelling in the last two tissues can be compared with that occurring in the connective tissue of the follicle wall before ovulation (Espey, 1974). Proteolytic enzymes have been implicated in the process of follicle rupture, and plasminogen activator (PA), a protease produced by follicular cells, is considered to be one of the key enzymes involved (Hsueh et al., 1988). Plasminogen activator converts plasminogen to plasmin, which activates collagenase and degrades proteoglycan.

It was shown, using porcine granulosa cells from large and small follicles, that PA activity was three times greater in granulosa cells from large follicles after culture for $24 \mathrm{~h}$ (Bagnell, 1991). Addition of relaxin had no effect on PA activity, whereas addition of FSH resulted in a twofold increase in PA activity by granulosa cells from both small and large follicles. However, relaxin enhanced the effects of FSH by increasing PA activity of granulosa cells when compared with cells cultured with FSH alone. These results are similar to those in rats in which gonadotrophin priming of granulosa cells was required to demonstrate an effect of relaxin on PA activity (Too et al., 1984). In addition, the increased PA activity of granulosa cells from large follicles is consistent with data showing that PA activity in the porcine preovulatory follicle increased with approaching ovulation (Politis et al., 1990). 


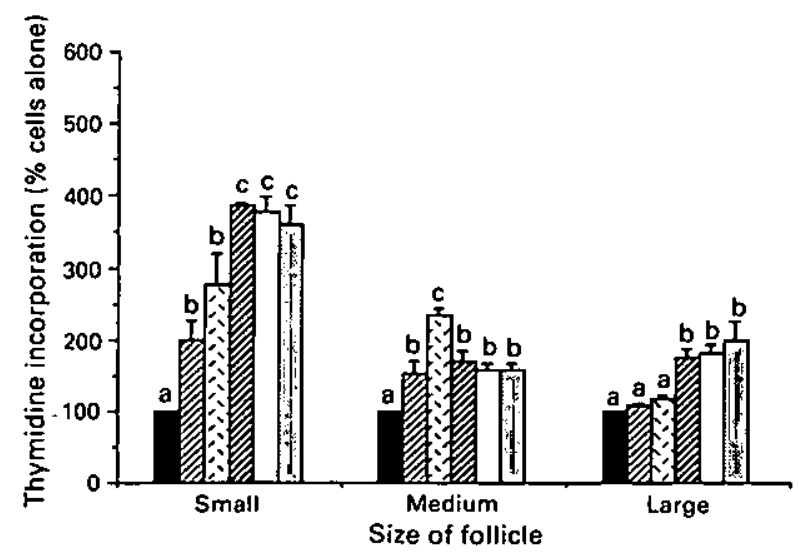

Fig. 2. Effect of relaxin on $\left[{ }^{3} \mathrm{H} \mid\right.$ thymidine incorporation by granulosa cells from developing pig follicles. Cells from small (1-2 $\mathrm{mm})$, medium (3-5 mm) and large $(\geq 6 \mathrm{~mm}$ ) follicles were plated in serum-containing media for $48 \mathrm{~h}$. After attachment, cells were incubated in serum-free media with relaxin ( 23$) 1$,

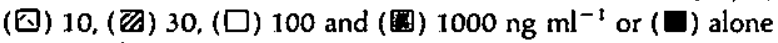
for $24 \mathrm{~h} . \mathrm{l}^{3} \mathrm{H}$ |thymidine incorporation into DNA was then determined. Data are means \pm SEM of four experiments. Bars with different superscripts within each follicle size were significantly different $(P<0.05)$ (Reproduced with permission from Zhang and Bagnell, 1993).

The anabolic effects of relaxin in other reproductive tissues (Hall et al., 1990; Hurley et al., 1991) and of members of the insulin-like family of hormones on ovarian cells (Baranao and Hammond, 1984; May et al., 1988) prompted us to investigate the effects of relaxin alone and in combination with insulin or IGF-I on porcine follicular cells (Zhang and Bagnell, 1993). Relaxin alone stimulated [ ${ }^{3} \mathrm{H}$ )thymidine incorporation into DNA of granulosa cells from small, medium and large porcine follicles (Fig. 2). After 6 days of exposure to relaxin in vitro, there was a dose-dependent response in the proliferation of granulosa cells from small follicles (Fig. 3). The increased numbers of cells were correlated with the relaxin-induced increase in $\left[{ }^{3} \mathrm{H}\right]$ thymidine incorporation into DNA in these cells. In addition, relaxin increased insulin- and IGF-Iinduced DNA synthesis in granulosa cells at all stages of follicular development, suggesting an interaction of relaxin with these factors during follicular growth. These observations indicate that relaxin acts as a growth factor in developing pig follicles.

The changes in relaxin production with development of the preovulatory follicle, the increase in granulosa cell proteolytic enzyme activity in vitro in response to relaxin and the growth-promoting action of relaxin on granulosa cells support the concept of an autocrine or paracrine role for relaxin in preovulatory follicular development in pigs. Whether relaxin acts on other cells in the ovary or plays a role in the remodelling of connective tissue and rupture of the follicle in vivo is unknown. Relaxin has been shown to influence aromatase activity of human endometrial stromal cells (Tseng et al., 1987), but a similar action on porcine granulosa cells was not observed (Bagnell, 1991). Other possible actions of relaxin within the ovary, such as altering collagen content of the follicle wall or influencing smooth muscle activity have not been investigated. Evidence for ovarian relaxin receptors is based on the biological response of granulosa cells to relaxin in vitro; however, an ovarian relaxin receptor remains to be characterized.

\section{Uterine accommodation}

The establishment and maintenance of pregnancy involves metabolic and physical changes in the uterus to accommodate the growing fetuses. Relaxin is an important regulator of myometrial activity during pregnancy; however, a lesser understood action is the ability of relaxin to stimulate uterine growth. In rats, uterotrophic actions of relaxin are suggested from studies showing imbibition of water by uterine 


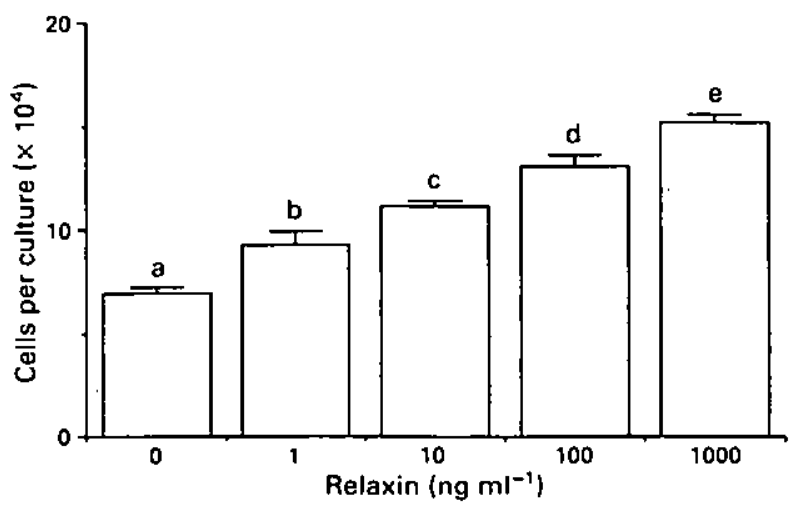

Fig. 3. Effects of relaxin on proliferation of granulosa cells from small pig follicles. Granulosa cells from small follicles were plated as described in Fig. 2. After attachment, cells were incubated in serum-free media with relaxin (1-1000 $\mathrm{ng} \mathrm{ml}^{-1}$ ) for 6 days. Media were changed at $72 \mathrm{~h}$; fresh hormone was added for an additional $72 \mathrm{~h}$ and number of cells was counted. Data are means \pm SEM for four experiments. Bars with different superscripts were significantly different $(P<0.05)$ (Reproduced with permission from Zhang and Bagnell, 1993).

tissues and increased amounts of soluble protein, collagen, glycosaminoglycans and glycogen in the uterus (Steinetz et al., 1957; Vasilenko et al., 1980, 1981; Vasilenko and Mead, 1987). The increase in uterine weight after administration of relaxin can be attributed largely to the accumulation of fluid in uterine tissues, which may be due to increased vascularity or enhanced blood flow (Vasilenko et al., 1986). However, on the basis of these observations, Vasilenko and Mead (1987) postulated a uterotrophic role for relaxin in the rat utenus to accommodate the rapidly growing fetuses during early pregnancy. Hall et al. (1990) demonstrated uterotrophic effects of relaxin based on increased uterine dry weight, protein and DNA content, following administration of relaxin to prepubertal gilts. These latter changes were accompanied by cervical softening and imbibition of water by the uterus. In a recent study, Hall et al. (1992) showed that relaxin can promote hypertrophic and hyperplastic growth of the pig uterus in the presence or absence of oestrogen or progesterone. In addition, oestrogen appears to enhance the effects of relaxin stimulated uterine growth, which is consistent with results from studies in rats (Kroc et al., 1959; Vasilenko and Mead, 1987). Although the mechanisms by which relaxin stimulates uterine growth have not been defined, it is possible that relaxin may act directly through a uterine receptor which in tum could be regulated by oestrogen (Mercado-Simmen et al., 1982).

\section{Myometrial relaxation}

Relaxin-induced inhibition of uterine smooth muscle activity in vivo and in vitro has been well documented in pregnant and nonpregnant pigs (Porter, 1979b). Relaxin is thought to prevent premature labour, but, paradoxically, it facilitates delivery by inducing cervical ripening before parturition (BryantGreenwood, 1982). To explain this apparent paradox, Porter (1979b) suggested that relaxin inhibits uterine contraction during the antepartum period of progesterone withdrawal while priming the myometrium to respond to oxytocic signals that generate highly coordinated labour contractions and expulsion of the fetuses. This explanation is supported by the results of studies using the oestrogen-primed, ovariectomized nonpregnant mini-pig, showing that relaxin lowers the frequency of contractions in vitro, without affecting the amplitude (Porter and Watts, 1986). In addition, the myometrium remained responsive to oxytocin despite the infusion of relaxin. These studies were supported and extended by showing that in myometrial tissues from pregnant and nonpregnant pigs, relaxin inhibited spontaneous contractions in vitro, but had no effect on oxytocin-, $\mathrm{PGE}_{2}-$ or $\mathrm{PGF}_{2 \alpha}$-induced contractions (Maclennan et al., 1986; Pupula and MacLennan, 1989). 


\section{Cervical softening}

During most of mammalian pregnancy, the cervix is a firm, inextensible barrier protecting the fetus from the external environment and premature delivery. However, in late pregnancy, the tensile properties of the cervix change promoting increased distensibility or 'softening' and dilation to allow passage of the fetuses at parturition. In the firm cervix, collagen fibrils are densely arranged with little proteoglycan-rich matrix, whereas in the softened cervix, the collagen fibrils are dispersed and randomly oriented with an increase in matrix separating the fibrils (Sherwood, 1988). There is good evidence that relaxin plays a major role in the remodelling of the cervix in late pregnancy in a number of species and this has been the subject of several reviews (Steinetz et al., 1980; Porter, 1981).

Zarrow et al. (1956) were the first to report that porcine relaxin following oestrogen priming produced maximum dilation of the cervix by the third day of treatment in pigs. Oestrogen alone has been shown to promote cervical softening in pregnant sheep and women (Fitzpatrick and Liggins, 1980); however, cervical remodelling in pigs cannot be attributed to oestrogen alone. During oestrus, when oestrogen concentrations are high, the porcine cervix is relatively firm in comparison with other stages of the cycle (Rigby, 1967; Meredith, 1977). In addition, treatment of ovariectomized, nonpregnant pigs with oestrogen caused constriction of the cervix (Smith and Nalbandov, 1958), whereas cervical softening was reported in prepubertal gilts treated with relaxin in vivo (Hall et al., 1990). Relaxin-induced growth and softening of the cervix in rats and mice appears to be oestrogen dependent (Kroc et al., 1959). Likewise in pregnant pigs, marked changes in the physical properties of the cervix have been reported which were temporally correlated with high serum oestrogen or oestrogen and relaxin (Eldridge-White et al., 1989). In ovariectomized pregnant pigs, increases in the physical properties (extensibility, lumen diameter and wet weight) of both the uterine and vaginal portions of the cervix occur only after treatment with relaxin (O'Day et al., 1989). These relaxin-induced physical changes in the cervix are correlated with changes in biochemical composition of the tissue. For example, relaxin treatment decreased collagen concentrations while increasing water content, dry weight and glycosaminoglycan:collagen ratio in the cervix of ovariectomized gilts during the last third of gestation (O'Day-Bowman et al., 1991). These data provide an explanation for the observations that birth is prolonged and the incidence of live births is low in ovariectomized pigs, unless relaxin replacement therapy is provided (Nara et al., 1982). Taken together, these data support the concept that relaxin plays an important role in the preparation of the cervix for delivery.

\section{Mammary gland growth}

Mammotrophic effects of relaxin have been described in guinea-pigs (Garrett and Talmadge, 1952), mice (Bani and Bigazzi, 1984), rabbits (Garrett and Talmadge, 1952) and rats (Wright and Anderson, 1982). In addition, relaxin has been reported to stimulate growth of human MCF-7 breast cancer cells (Bigazzi et al., 1992). Indirect evidence for mammotrophic effects of ovarian relaxin in pregnant pigs came from studies in which ovariectomy at midgestation resulted in a delay or inhibition of mammary growth (Elliott and Dziuk, 1973; Buttle, 1988). Hurley et al. (1991) examined the effects of relaxin on the development of mammary tissue during the last third of pregnancy in gilts. Ovariectomy on day 80 or 100 , followed by progesterone replacement, resulted in significant reduction in mammary parenchymal tissue development supporting the concept that the ovary is important for mammary growth. Relaxin therapy restored mammary gland growth to control values indicating that relaxin plays a role in porcine mammary development in late gestation.

\section{Biological Actions of Relaxin in Male Pigs}

It has been shown that purified porcine relaxin can maintain or increase sperm motility; in contrast, antiserum to porcine relaxin inhibits sperm motility (Juang et al., 1989). In addition, the presence of immunoreactive relaxin in boar seminal plasma was highly correlated with increased sperm motility (Juang et al, 1990). These studies indicate a potential role for relaxin in boars, but it is clear that much work is needed to determine the source and biological actions of relaxin in males. 


\section{Conclusion}

Although multiple sources and biological actions for relaxin have been identified in pigs, important fundamental questions remain concerning the control of relaxin synthesis and its biological role as both a systemic and locally acting hormone during various reproductive states. The contribution of relaxin to the process of follicular growth, uterine accommodation and mammary development support a growthpromoting effect for the hormone in target tissues. Furthermore, regulation of porcine relaxin secretion, its mechanism of action, isolation and characterization of relaxin receptors from target tissues are areas of investigation that will provide important fields of study in the future.

This work was supported by NIH Grant HD 20624 and the N\} Agriculture Experiment Station, Publication No. F-06115-1-93 (to CAB).

\section{References}

Afele S, Bryant-Greenwood GD, Chamley WA and Dax EM (1979) Plasma relaxin immunoactivity in the pig at parturition and during nuzzling and suckling Jotirtal of Reproduction and Fertility $56 \quad 451-457$

Ali SM, McMurtry JP, Bagnell CA and Bryant-Greenwood GD (1986) Immunocytochemical localization of relaxin in corpora lutea of sows throughout the estrous cycle Biology of Repro. duction 34 139-143

Anderson LL, Ford JJ, Melampy RM and Cox DF (1973) Relaxin in porcine corpora lutea during pregnancy and after hysterectomy American Joumal of Physiology 225 1215-1219

Anderson LL, Adair V, Stromer MH and McDonald WG (1983) Relaxin production and release after hysterectomy in the pig Endocrinology $113677-686$

Arakaki RF, Kleinfeld RG and Bryant-Greenwood FC (1980) Immunofluorescence studies using antisera to crude and to purified porcine relaxin Biology of Reproduction 23 153-159

Bagnell CA (1991) Production and biologic action of relaxin within the ovarian follicle: an overview Steroids 56 242-246

Bagnell CA, Greenwood FC and Bryant-Greenwood CD (1984) A paracrine role for follicular relaxin. In Gonadal Peptides and their Biological Significance pp 299-308 Eds MR Sairam and L Atkinson. World Publishing Co., Singapore

Bagnell CA, Frando LB, Downey BR, Tsang BK and Ainsworth L (1987) Localization of relaxin in the pig follicle during preovulatory development Biology of Reproduction 37 235-240

Bagnell CA, Ayau E, Downey BR, Tsang BK and Ainsworth L (1989) Localization of relaxin during formation of the porcine corpus luteum Biology of Reproduction 40 835-841

Bagnell CA, Tashima L, Tsark W, Ali SM and McMurtry JP (1990a) Relaxin gene expression in the sow corpus luteum during the cycle, pregnancy and lactation Endocrinology 126 $2514-2520$

Bagnell CA, Tsark W, Tashima L, Downey BR, Tsang BK and Ainsworth L (1990b) Relaxin gene expression in the porcine follicle during preovulatory development induced by gonadotropins Joumal of Molecular Endocrinology 5 211-219

Bagnell CA, Zhang Q, Connor ML, Downey BR, Tsang BK and Ainsworth L (1993) Developmental expression of the relaxin gene in the porcine corpus luteum Joumal of Molecular Endocrinology 10 87-97

Bani $G$ and Bigazzi M (1984) Morphological changes induced in mouse mammary gland by porcine and human relaxin Acta Anatomica 119 149-154

Baranao JLS and Hammond JM (1984) Comparative effects of insulin and insulin-like growth factors on DNA synthesis and differentiation of porcine granulosa cells Biochemical and Biophysical Research Communications 124 484-490
Belt WD, Anderson LL, Cavazos LF and Melampy RM (1971) Cytoplasmic granules and relaxin levels in porcine corpora lutea Endocrinology 89 1-10

Bigazzi M, Brandi ML, Bani G and Bani-Sacchi T (1992) Relaxin influences the growth of MCF-7 breast cancer cells Cancer $70639-643$

Blundel] TL and Humbel RE (1980) Hormone families: pancreatic hormones and homologous growth factors Nature 287 781-787

Bryant-Greenwood GD (1982) Relaxin as a new hormone Endocrine Reviews 3 62-90

Bryant-Greenwood GD, Jeffrey R, Ralph MM and Seamark RF (1980) Relaxin production by the porcine ovarian Graafian follicle in vitro Biology of Repraduction $23792-800$

Buttle HL (1988) Role of the ovaries in inducing mammogenesis in pregnant pigs Joumal of Endocrinology $11841-45$

Channing CP and Ledwitz-Rigby F (1975) Methods for assessing hormone-mediated differentiation of ovarian cells in culture and in short-term incubations Methods in Enzymology 39 183-229

Comer CW (1944) Alkaline phosphatase in the ovarian follicle and in the corpora lutea Science 100 270-271

Denning-Kendall PA, Guldenaar SEF and Wathes DC (1989) Evidence for a switch in the site of relaxin production from small theca-derived cells to large luteal cells during early pregnancy in the pig Joumal of Reproduction and Fertility 85 261-271

Dubois MP and Dacheux JL, (1978) Relaxin, a male hormone? Cell and Tissue Research 187 201-214

Einspanier R, Pitzel L, Wutte W, Hagendorff G, Preub KD, Kardalinou E and Scheit KH (1986) Demonstration of mRNAs for oxytocin and prolactin in porcine granulosa and luteal cells FEBS Leiters $204 \quad 37-40$

Eldridge-White RA, Easter DM, Heaton DM, O'Day MB, Petersen RD, Shanks MK, Tarbell MK and Sherwood OD (1989) Hormonal control of the cervix in pregnant gilts. I. Changes in the physical properties of the cervix correlate temporally with elevated serum levels of estrogen and relaxin Endocrinology 125 2996-3003

Elliott AR and Dzuik PJ (1973) Minimum daily dose of progesterone and plasma concentration for maintenance of pregnancy in ovariectomized gilts Biology of Reproduction 9 300-304

Espey LL (1974) Ovulation as an inflammatory reaction Biology of Reproduction 10 216-235

Evans G, Wathes DC, King GJ, Armstrong DT and Porter DG (1983) Changes in relaxin production by the theca during the preovulatory period of the pig Jountal of Reproduction and Fertility $69677-683$ 
Felder KJ, Molina JR, Benoit AM and Anderson LL (1986) Precise timing for peak relaxin and decreased progesterone secretion after hysterectomy in the pig Endacrinology 119 1502-1509

Fields PA and Fields M] (1985) Ultrastructural localization of relaxin in the corpus luteum of nonpregnant, pseudopregnant and pregnant pigs Biology of Reproduction 32 1169-1179

Fields PA, lee AB, Haab LM, Hwang JJ and Sherwood OD (1992) Evidence for a dual source of relaxin in the pregnant rat: immunolocalization in the corpora lutea and endometrium Entocrinology 130 2985-2990

Fitzpatrick RJ and Liggins CC (1980) Effects of prostaglandins on the cervix of pregnant women and sheep. In Dilatation of the Cervix pp 287-300 Eds F Naftolin and PG Stubblefield. Raven Press, New York

Gagliardi CL, Goldsmith LT, Saketos M, Weiss G $_{\text {and Schmidt }}$ CL (1992) Human chorionic gonadotropin stimulation of relaxin secretion by luteinized human granulosa cells Fertility and Sievility 58 314-320

Garrett FA and Talmadge RV (1952) The influence of relaxin on mammary gland development in guinea pigs and rabbits Jounal of Endacrinology 8 336-341

Gast MJ (1982) Studies of luteal generation and processing of the high molecular weight relaxin precursor Anuals of the New York Academy of Sciences 380 111-125

Gast MJ (1983) Characterization of preprorelaxin by tryptic digestion and inhibition of its conversion to prorelaxin by amino acid analogs Joumal of Biological Chemistry 258 $9001-9004$

Greenwood FC. Mercado-Simmen RC and Bryant-Greenwood GD (1981) Insulin-related peptides examined by radioimmunoassay and radioreceptor assay: a note. In Relaxin pp 97-98 Eds GD Bryant-Greenwood. HD Niall and FC Greenwood. Elsevier/North Holland, New York

Haley J, Hudson P. Scanlon D. Cronk M, Shine J, Tregear J and Niall $H$ (1982) Porcine relaxin: molecular cloning and cDNA structure DNA 1 I55-161

Hall JA, Cantley TC, Day BN and Anthony RV (1990) Uterotropic actions of relaxin in prepubertal gilts Biology of Reproduction 42 769-774

Hall JA, Cantley TC, Galvin JM, Day BN and Anthony RV (1992) Influence of ovarian steroids on relaxin-induced uterine growth in ovariectomized gilts Endocrinology 130 3159-3166

Hernandez, ER, Resnick CE, Svoboda ME, Van Wyk JJ, Payne DW and Adashi EY (1988) Somatomedin-C/insulin-like growth factor $I$ as an enhancer of androgen biosynthesis by cultured rat ovarian cells Endocrinology 122 1603-1612

Hisaw FL, Fevold HL and Meyer RK (1930) The corpus luteum hormone: methods of extraction Physiological Zoology 3 135-144

Hsueh AJW, Liu YX, Cajander SB and Ny T (1988) Molecular mechanisms in the hormonal regulation of plasminogen activator activity in ovarian granulosa cells and cumulusoocyte complexes. In Progress in Clinical and Biological Research Vol. 267 pP 227-257 Eds FP Haseltine and NL First. Alan R Liss Inc, New York

Huang C, Stromer MH and Anderson L., (1991) Abrupt shifts in relaxin and progesterone secretion by aging luteal cells: luteotropic response in hysterectomized and pregnant pigs Endocrinology 128 165-173

Hurley WL, Doane RM, O'Day-Bowman MB, Winn RJ, Mojonnier LE and Sherwood OD (1991) Effect of relaxin on mammary development in ovariectomized pregnant gilts Eudocrinology 128 I285-1290
Issacs $\mathbf{N}$ and Dodson $\mathbf{G}$ (1981) Models of relaxin. In Relarin pp 101-106 Eds GD Bryant-Greenwood, HD Niall and FC Greenwood. Elsevier/North-Holland, Amsterdam

James R, Niall HD, Kwok S and Bryant-Greenwood GD (1977) Primary structure of porcine relaxin and homology with insulin and related growth factors Nature $267544-546$

Juang $\mathrm{HH}$, Musah Al, Schwabe C and Anderson LL (1989) Effect of relaxin and antirelaxin serum on porcine sperm motility Animal Reproduction Science 20 21-29

Juang HH, Musah AI, Schwabe C and Anderson LL (1990) Immunoreactive relaxin in boar seminal plasma and its correlation with sperm motility Animal Reproduction Science 22 47-53

Kendall JZ, Plopper CG and Bryant-Greenwood GD (1978) Ultrastructural immunoperoxidase demonstration of relaxin in corpora lutea from a pregnant sow Biology of Reproduction 18 94-98

Kotwica G. Dusza L, Ciereszko R, Okrasa S and Schams D (1991) Evidence for relaxin and progesterone synchronous secretion on days 13-17 of the oestrous cycle in sows Experimental and Clinical Endocrinology 98 3-8

Kroc RL, Steinetz BG and Bech VL (1959) The effects of estrogens, progestagens and relaxin in pregnant and nompreg. nant laboratory rodents Anuals of the Neto York Academy of Sciences 75 942-980

Lee VH and Fields PA (1990) Rabbit endometrial relaxin: immunohistochemical localization during pre-implantation. pregnancy and lactation Biology of Reproduction 42 737-745

Lobb DK and Porter DG (1992) Rapid increase in relaxin gene expression in early pregnancy in the pig Molecular and Celhular Endocrinology 89 R5-R8

Loeken MR, Channing CP, D'Eletto R and Weiss G (1983) Stimulatory effect of luteinization hormone upon relaxin secretion by cultured porcine granulosa cells Endocrinology 112 769-771

MacLennan AH, Grant P and Ness D (1986) Effect of porcine relaxin and progesterone on rat, pig and human myometrial activity in vitro Jountal of Reproductive Medicine 31 43-49

Matsumoto D and Chamley WA (1980) Identification of relaxins in porcine follicular fluid and in the ovary of the immature sow Joumal of Reproduction and Fertility 58 369-375

May JC, Frost J and Schomberg DW (1988) Differential effects of epidermal growth factors, somatomedin-C/insulin like growth factor-l and transforming growth factor B on porcine granulosa cell DNA synthesis and cell proliferation Endocrinology 123 168-179

Mercado-Simmen RC, Goodwin JE, Ueno MS, Yamamoto SY and Bryant-Greenwood GD (1982) Relaxin receptors in the myometrium and cervix of the pig Biology of Reproduction 26 120-128

Meredith MJ (1977) Clinical exarnination of the ovaries and cervix of the sow Veterinary Record 10170 (Abstract)

Messine $O$. Barros SM, Chang WW, Thatcher WW and Fields MJ (1989) Relaxin secretion during the cycle and early pregnancy in the pig Biology of Reproduction 4058 (Abstract)

Nara BS, Welk FA, Rutherford JE, Sherwood OD and First NL. (1982) Effect of relaxin on parturition and frequency of live births in pigs Joumal of Reproduction and Fertility 66 359-365

O'Byme EM, Tabachnick M, Anderson LL and Steinetz BG (1989) Characterization of the circulating form of porcine relaxin: biological activity and terminal amino acids Endocrinology 124 2920-2927

O'Day MB, Winn RJ, Easter RA, Dziuk PJ and Sherwood OD (1989) Homonal control of the cervix in pregnant gilts. II. Relaxin promotes changes in the physical properties of the 
cervix in ovariectomized hormone-treated pregnant gilts Endocrinology 125 3004-3010

O'Day-Bowman MB, Winn RJ, Dziuk PJ, Lindley ER and Sherwood OD (1991) Hormonal control of the cervix in pregnant gilts. III. Relaxin's influence on cervical biochemical properties in ovariectomized hormone-treated pregnant gilts Endocrinology 129 1967-1976

Olefsky JM, Saekow M and Kroc RL (1982) Potentiation of insulin binding and insulin action by purified porcine relaxin Annals of the New York Academy of Sciences $\mathbf{3 8 0}$ 200-215

Pardo RJ and Larkin LH (1982) Localization of relaxin in endometrial gland cells of pregnant, lactating and ovariectomized homone-treated guinea pigs American Joumal of Anatomy 164 79-90

Politis I, Srikandakumar A, Turner JD. Tsang BK, Ainsworth L. and Downey BR (1990) Changes in the ovarian plasminogen activator system during preovulatory development in the PMSG/hCG-treated gilt Biology of Reproduction 43 636-642

Porter DG (1979a) Relaxin: old hormone new prospect. In Oxford Reviews of Reproductive Biology. pp 1-57 Ed. CA Finn. Clarendon Press, Oxford

Porter DG (1979b) The myometrium and the relaxin enigma Animal Reproduction Science 2 77-96

Porter DG (1981) Relaxin and cervical softening: a review The Cervix in Pregnancy and Labour pp 85-99 Eds DA Ellwood and $A B M$ Anderson. Churchill Livingstone, New York

Porter DG and Watts AD (1986) Relaxin and progesterone are myometrial inhibitors in the ovariectomized non-pregnant mini-pig Joumal of Reproduction and Ferility 76 205-213

Pupula M and Maclennan AH (1989) Effect of porcine relaxin on spontancous, oxytocin-driven and prostaglandin-driven pig myometrial activity in vitro Jounal of Reproductive Medicine 34 819-823

Rawitch AB, Moore WV and Frieden EH (1980) Relaxin-insulin homology: predictions of secondary structure and lack of competitive binding Intemational Joumal of Biochemistry 11 357-362

Rigby JP (1967) The cervix of the sow during oestrus Veterinary Record 80672 (Abstract)

Schwabe C and McDonald JK (1977) Relaxin: a disulfide homolog of insulin Srience 197 914-915

Schwabe C, McDonald JK and Steinetz BG (1976) Primary structure of the A chain of porcine relaxin Biochemical and Bio. physical Research Communtications 70 397-405

Schwabe C. Steinetz BG, Weiss G. Segaloff A, McDonald JK, O'Byme EM, Hochman J, Carriere B and Goldsmith L (1978) Relaxin Recent Progress in Honnone Research 34 123-199

Setliff JA and Greenwood FC (1981) Porcine uterine relaxin: a note. In Relaxin pp 75-77 Eds GD Bryant-Greenwood, HD Niall and FC Greenwood. Elsevier/North Holland, Amsterdam

Sherwood OD (1988) Relaxin. Physiology of Reproduction pp 585-673 Ed. E Knobil and J Neill. Raven Press, Ltd, New York

Sherwood OD and O'Byrne EM (1974) Purification and characterization of porcine relaxin Archives of Biochemistry and Biophysics 160 185-196

Sherwood OD and Rutherford JE (1981) Relaxin immunoactivity levels in ovarian extracts obtained from rats during various reproductive states and from adult cycling pigs Endocrinology 108 1171-1177

Sherwood OD, Rosentreter KR and Birkhimer ML (1975a) Development of a radioimmunoassay for porcine relaxin using ${ }^{12}$ J-labeled polytyrosyl-relaxin Endocrinology 96 1106-1113

Sherwood OD, Chang CC, BeVier GW and Dziuk PJ (1975b) Radioimmunoassay of plasma relaxin levels throughout pregnancy and at parturition in the pig Endocrinology 94 834-837

Sherwood OD, Nara BS, Welk FA, First Nl, and Rutherford JE (1981) Relaxin levels in the matemal plasma of pigs before, during and after parturition and before, during and after suckling Biology of Reproduction 25 65-71

Smith JC and Nalbandov AV (1958) The role of hormones in the relaxation of the uterine portion of the cervix in swine American Joumal of Veterinary Research 19 15-18

Steinetz BG, Beach VL, Blye RP and Kroc RL (1957) Changes in the composition of the rat uterus following a single injection of relaxin Endocrinology 61 287-292

Steinetz BG, O'Byme EM and Kroc RL (1980) The role of relaxin in cervical softening during pregnancy in mammals. In Dilation of the Uterine Cervix pp 157-177 Eds F Naftolin and PG Stubblefield. Raven Press, New York

Taylor MJ and Clark CL (1988a) Regulation of relaxin release from monodispersed porcine luteal cells: effect of calcium ionophore A23187 and calcium channel blockers Endocrinology 123 1893-1901

Taylor MJ and Clark Cl (1988b) inhibitory effect of analogs of cyclic nucleotides and cholera toxin on relaxin from cultured porcine luteal cells Biology of Reproduction 38 315-323

Taylor MJ and Clark CL (1989) Analysis of relaxin release by cultured porcine luteal cells using a reverse hemolytic plaque assay: effects of arachidonic acid, cyclo- and lipooxygenase blockers, phospholipase A2 and mellitin Endocrinology 125 1389-1397

Taylor MJ, Clark CL and Frawley LS (1987) Analysis of relaxin release from cultured porcine luteal cells by reverse hemolytic plaque assay: influence of gestational age and prostaglandin $\mathrm{F}_{2 \mathrm{~s}}$ Endocrinology 120 2085-2091

Too CKL, Bryant-Greenwood GD and Greenwood FC (1984) Relaxin increases the release of plasminogen activator, collagenase and proteoglycanase from rat granulosa cells in vitro Endocrinology 115 1043-1050

Tseng L, Mazella J and Chen G (1987) Effect of relaxin on aromatase activity in human endometrial stromal cells Endocrinology $1202220-2224$

Vasilenko P and Mead PJ (1987) Growth-promoting effects of relaxin and related compositional changes in the uterus, cervix and vagina of the rat Endocrinology 120 1370-1376

Vasilenko P, Frieden EH and Adams WC (1980) Effect of purified relaxin on uterine glycogen and protein in the rat Proceedings of the Society for Experimental Biology and Medicine 163 245-248

Vasilenko P, Adams WC and Frieden EH (1981) Uterine size and glycogen in cycling and pregnant rats: infuence of relaxin Biology of Reproduction 25 162-169

Vasilenko P. Mead JP and Weidmann JE (1986) Uterine growthpromoting effects of relaxin: a morphometric and histological analysis Biology of Reproduction 35 987-995

Wright LC and Anderson RR (1982) Effect of relaxin on mammary gland growth in female mice Proceedings of the Society for Experimental Biology and Medicine 101 707-709

Yamamoto S and Bryant-Greenwood CD (1981) The isolation of relaxin from boar testis. In Relaxin pp 71-74 Eds GD Bryant-Greenwood, HD Niall and FC Greenwood. Elsevier/ North Holland, Amsterdam

Yki-Jarvinen $\mathrm{H}$, Wahlstrom T. Tenhunen A, Koskimes $\mathrm{Al}$ and Seppala M (1984) The occurrence of relaxin in hyperstimu- 
lated human preovulatory follicles collected in an in vitro fertilization program Joumal of In Vitro Fertilization and Embryo Transfer 1 180-182

Zarrow MX, Neher GM, Sikes D. Brennan DM and Bullard JF (1956) Dilatation of the uterine cervix of the sow following treatment with relaxin American Joumal of Obstetrics and Gynecology 72 260-264

Zhang Q and Bagnell CA (1993) Relaxin stimulation of porcine granulosa cell deoxyribonucleic acid synthesis in vitro: interactions with insulin and insulin-like growth factor I Endocrinology 132 1642-1650

Zhang Z, Day BN, Samson WK and Anthony RV (1992) Relaxin is expressed by pregnant uterine epithelium during early pregnancy in swine 74th Anmal Meeting of Endocrine Sociely, San Antonio Abstract 1464 